\title{
Efektivitas Logoterapi dalam Meningkatkan Konsep Diri Remaja di Panti Sosial
}

\section{The Effectiveness of Logotherapy in Improving Adolescent's Self Concept in Foster Home}

\author{
Ellyana Dwi Farisandy ${ }^{1}$, Endang Retno Surjaningrum ${ }^{2}$ \\ 1,2Fakultas Psikologi, Universitas Airlangga
}

\begin{abstract}
This study aimed to examine the effectiveness of logotherapy to improve adolescent's self-concept. This study uses a true experiment method, namely pretest-posttest control group design. The subject of this study were eight male adolescents $\left(M_{\text {age }}=14.75\right.$ years, $\left.S D=0.88\right)$ who had low self-concepts. Data collection before and after the intervention used the Adolescents Self Concept Short Scale (ASCSS) developed by Veige and Leite (30 items, $\alpha=0.889$ ). The intervention provided were eight sessions of logotherapy intervention using MCP (Meaning Centered Psychotherapy) adapted from William S. Breitbart. Based on the results of data analysis tested through independent sample $t$-tests based on the gain score, it was found that there were significant differences regarding the self-concept between the experimental group and the control group $(t(6)=$ $4.9, p=0.003(p<0.05))$. The results showed that logotherapy had a great effect in improving adolescent's self-concept (effect size $=0.80$ ). Logotherapy is an effective intervention in improving adolescent's self-concept.
\end{abstract}

Keywords: adolescent; logotherapy; self-concept; foster home

Abstrak. Penelitian ini bertujuan untuk menguji efektivitas logoterapi untuk meningkatkan konsep diri remaja. Penelitian ini menggunakan metode true experiment yakni pretest-posttest control group design. Partisipan penelitian merupakan delapan remaja laki-laki $\left(M_{u s i n}=14.75\right.$ tahun, $S D=0.88$ ) yang memiliki konsep diri rendah. Pengumpulan data sebelum dan sesudah intervensi menggunakan alat ukur Adolescents Self Concept Short Scale (ASCSS) yang dikembangkan oleh Veige dan Leite (30 aitem, $\alpha=0.889$ ). Intervensi yang diberikan adalah delapan sesi intervensi logoterapi menggunakan MCP (Meaning Centered Psychotherapy) yang diadaptasi dari William S. Breitbart. Analisis data yang diuji melalui independent sample t-test berdasarkan gain score, diketahui bahwa terdapat perbedaan yang signifikan mengenai konsep diri antara kelompok eksperimen dan kelompok kontrol $(t(6)=$ $4.9, p=0.003(p<0.05))$. Hasil penelitian menunjukkan bahwa logoterapi memberikan efek besar dalam meningkatkan konsep diri remaja (effect size $=0.80$ ), artinya logoterapi adalah intervensi yang efektif dalam meningkatkan konsep diri remaja.

Keywords: konsep diri; logoterapi; remaja; panti sosial

Pandangan diri atau yang seringkali disebut sebagai konsep diri merupakan pengetahuan, evaluasi, hingga identitas diri yang mempengaruhi seseorang dalam berperilaku sesuai dengan konsep mengenai dirinya tersebut (McCrae \& Costa dalam Feist \& Feist, 2008). Individu yang memiliki konsep diri yang positif biasanya menunjukkan beberapa 
karakteristik yakni: percaya akan kemampuannya sendiri, optimis, berani menentukan tujuan hidup, serta mampu bersikap pun berpikir secara positif. Sebaliknya, individu yang memiliki konsep diri negatif cenderung tidak percaya diri, merasa bodoh dan tidak memiliki kemampuan, bersikap pesimis terhadap segala situasi, serta merasa tidak berguna (Andriasari, 2015; Marliani, 2016).

Perkembangan konsep diri pada individu merupakan sebuah proses yang terus menerus berjalan selama periode kehidupan manusia. Konsep diri tidak langsung ada pada saat kelahiran, namun berkembang secara bertahap seiring berjalannya usia. Pada masa remaja, konsep diri individu cenderung berubah secara cukup drastis dikarenakan banyaknya perubahan yang terjadi pada segala aspek kehidupan remaja. Remaja yang mulai mengambil peran sosial baru serta lingkungan interpersonal yang mengalami perubahan juga berkontribusi pada perkembangan konsep diri (Desmita, 2005; Rathus, 2017; Sebastian et al., 2008).

Pardede (2008) mengungkapkan bahwa konsep diri remaja yang merupakan anak jalanan adalah negatif. Hal ini dikarenakan mereka menganggap dirinya pembawa masalah dalam keluarga, merasa tidak yakin akan kemampuannya, merasa tidak diharapkan, serta merasa tidak ada yang menyayangi dirinya. Nasti (2016) juga mengungkapkan hal yang sama dimana konsep diri remaja yang merupakan anak jalanan adalah negatif. Berdasarkan aspek penilaian diri, mereka menilai diri mereka sebagai individu yang pesimis, iri terhadap orang lain, merasa gagal, malu dengan penampilan serta tubuh yang tidak terawat. Berdasar aspek penilaian sosial, mereka merasa tidak berguna, tidak memiliki sopan santun, dinilai negatif oleh orang lain, serta menjelekkan nama keluarga. Berdasar citra diri, mereka merasa bodoh, memliki banyak kekurangan, memiliki IQ rendah, merasa malu dengan keadaan orang tua, serta merasa tidak disayangi dan tidak diperhatikan oleh orang lain.

Penelitian terbaru dari Putri (2017) juga mengungkapkan secara lebih spesifik bahwa remaja yang tinggal di Pondok Sosial yakni panti asuhan memiliki konsep diri negatif. Hal ini dikarenakan mereka mengalami penolakan dari orang tua, kesepian tanpa keluarga, adanya pengaruh negatif dari sesama anak asuh, mendapatkan label negatif dari masyarakat, serta kurangnya perhatian dari pengasuh. Hal ini tentu sesuai dengan data awal dimana baik para pendamping dan pembina mengungkapkan mayoritas anak asuh yang berada di Panti X memiliki pandangan negatif terhadap dirinya sendiri.

Panti X merupakan salah satu LKSA yang berada dalam bimbingan Dinas Sosial Kota Surabaya. Tujuan utama dari Panti tersebut untuk membantu, melindungi, serta memberdayakan anak-anak yang memiliki masalah sosial yakni anak terlantar, anak jalanan dan anak nakal agar tidak terjerumus kepada perilaku menyimpang (Kampung Anak Negeri, 2018). Anak jalanan merupakan anak dengan usia 5-18 tahun yang menghabiskan mayoritas waktunya untuk berada di jalanan. Anak terlantar merupakan anak yang kebutuhan dasarnya tidak terpenuhi dengan baik, mulai dari jasmani, rohani, pun sosial dari keluarganya (Dinas Sosial Kota Surabaya, 2016). Di sisi lain, anak nakal merupakan anak yang pernah melakukan tindakan asusila serta memiliki kecenderungan untuk berperilaku kriminal (Kampung Anak Negeri, 2018). Anak asuh yang berada di Panti 
tersebut menganggap bahwa dirinya bodoh, gagal, tidak memiliki kemampuan atau kelebihan, tidak memiliki masa depan, tidak berharga, serta tidak dicintai oleh siapapun.

Papalia et al. (2004) mengungkapkan bahwa ada beberapa faktor yang dapat membentuk konsep diri seseorang, yakni orang tua, teman sebaya, masyarakat, serta proses belajar. Orang tua memerankan peran yang sangat penting dalam membentuk konsep diri individu (Overton, 2010). Pendamping di Panti X mengungkapkan bahwa sebelum mereka berada disini, mereka mengalami pengalaman-pengalaman yang menyakitkan seperti adanya penolakan dan/atau pengabaian serta mendapatkan kekerasan baik secara fisik maupun psikologis oleh orang tua.

"Sebenere kasian ya Mbak. Anak-anak ini ada yang ditelantarin sama keluarganya, jadi de'e nyari makan sendiri di jalan, entah ngamen atau ya minta-minta di lampu merah. Terus B ini katanya dipukul tiap hari lek pulang malem pakai ikat pinggang sama ayahnya"-PE

Hal ini sesuai dengan pendapat Marliani (2016) yang menjelaskan bahwa orang tua yang mengabaikan, kurang memberikan kasih sayang, serta memberikan kekerasan fisik akan membuat anak cenderung memiliki konsep diri yang negatif. Rathus (2017) juga menambahkan bahwa orang tua yang tidak memiliki kedekatan emosional pada anak juga dapat memengaruhi konsep diri anak menjadi negatif.

Teman sebaya juga berperan dalam membentuk konsep diri individu. Hal ini dikaitkan dengan penerimaan sosial oleh teman sebaya terkait dengan kompetensi pada bidang akademik, sosial, dan atletik (Rathus, 2017). Beberapa anak di Panti X mengungkapkan bahwa ia seringkali dirundung oleh teman sebayanya. Perilaku perundungan tidak hanya secara verbal namun juga secara fisik. Hal ini dapat memengaruhi pandangan dan evaluasi individu terhadap dirinya sendiri sehingga memunculkan konsep diri negatif. Selain itu, Rathus (2017) mengungkapkan bahwa guru memiliki kontribusi yang cukup penting untuk membentuk konsep diri anak. Beberapa anak di panti sosial $\mathrm{X}$ mengungkapkan bahwa ia kerap diberikan perlakuan yang tidak adil karena mereka adalah anak terlantar maupun anak jalanan. Ia juga beberapa kali dilabel sebagai "anak nakal" dan "anak bodoh" oleh gurunya. DE (15 tahun) mengungkapkan:

"Aku ini bodoh mbak. Yo orang tuaku apalagi ibukku ae sering ngomong ke aku lek aku ini bodoh. Nilai ku di sekolah tho elek-elek, gak onok seng bagus. Lho aku sekarang umur 15 tapi yo masian kelas 5SD. Guruku juga yo gitu nganggepe aku bodoh sama nakal soale sering mbolos, sering telat, sering dapet nilai jelek, yo gitu"

Hal ini sesuai dengan penuturan Marliani (2016) yang mengungkapkan bahwa guru yang tidak mengapresiasi kemampuan dan melabel negatif anak serta kurangnya penerimaan sosial dari lingkungan juga memengaruhi konsep diri anak menjadi negatif.

Masyarakat juga dapat memengaruhi konsep diri anak (Papalia et al., 2004). Anak jalanan seringkali mendapatkan label negatif dari masyarakat bahwa mereka merupakan sampah ekonomi dan sosial karena posisi mereka dalam masyarakat tidak berfungsi serta 
mereka yang seringkali melakukan perilaku antisosial (Obioha, 2009). Hal ini sesuai dengan data yang penulis dapatkan dari Pembina Panti X. Pembina mengungkapkan bahwa mereka di label negatif oleh orang-orang di lingkungan sekitarnya, baik sebagai 'anak nakal, 'anak bodoh', 'anak tidak bisa diatur', dan sebagainya. Mereka juga seringkali dipandang sebelah mata dikarenakan pakaian yang tidak rapi dan lusuh, tubuh yang tidak terawat, serta adanya luka di sekujur tubuhnya.

Ketika berada di Panti $X$, mereka juga tidak mendapatkan pengasuhan yang hangat dan intensif oleh pendamping. Hal ini dikarenakan hanya terdapat empat orang pendamping yang bekerja secara shift dan mendampingi 35 anak secara bergantian. Pembina maupun pendamping di Panti $X$ juga menerapkan disiplin yang keras terhadap anak asuh. Mazaya dan Supradewi (2011) melanjutkan bahwa fokus panti asuhan hanya untuk memenuhi kebutuhan primer seperti sandang, pangan, dan papan sehingga kebutuhan emosional dan perkembangan anak masih kurang diperhatikan. Anak dilihat hanya sebagai makhluk biologis, bukan sebagai makhluk psikologis dan sosial. Padahal, selain kebutuhan primer yang telah disediakan untuk memenuhi kebutuhan biologis, anak juga membutuhkan perhatian, cinta tanpa syarat, dukungan sebagai bentuk pemenuhan psikologisnya, pun hubungan dengan orang yang signifikan pun lingkungannya sebagai bentuk dari pemenuhan sosialnya (Mazaya \& Supradewi, 2011). Rola (dalam Putri, 2017) melanjutkan bahwa walaupun panti asuhan telah menjamin kebutuhan fisiologis individu, namun anak-anak kurang mendapatkan kasih sayang karena pengasuh pun pembimbing harus membagi perhatian mereka tidak hanya pada satu anak namun beberapa anak. Kondisi yang telah dialami oleh remaja di Panti X membuat mereka memandang rendah atas dirinya sehingga memunculkan konsep diri yang negatif.

Berdasarkan penjabaran yang telah dijelaskan di atas, logoterapi dapat menjadi salah satu alternatif yang digunakan untuk meningkatkan konsep diri remaja yang berada di Panti X Surabaya. Corey (2013) menjelaskan bahwa logoterapi merupakan suatu teknik intervensi yang dirancang untuk membantu individu dalam mengurangi ketidakbermaknaan dan kehampaan eksistensial melalui penemuan makna hidup. Terdapat beberapa penelitian sebelumnya yang menjelaskan mengenai keefektifan logoterapi yang digunakan untuk subjek remaja dan dewasa awal, yakni untuk meningkatkan makna hidup dan kesejahteraan spiritual remaja dengan kanker stadium akhir, meningkatkan kualitas hidup remaja perempuan dengan PTSD, meningkatkan makna hidup dan kesejahteraan subjektif mahasiswa, meningkatkan makna hidup dan menurunkan depresi mahasiswa, serta meningkatkan penerimaan anak broken home (Kang et al., 2009; Doğan et al., 2012; Shoakaazemi et al., 2012; Robatmili et al., 2014; Erlangga, 2017).

Terkait konsep diri, logoterapi juga efektif dalam meningkatkan konsep diri baik pada subjek dewasa awal maupun lansia. Karimi dan Memarzadeh (2016) melakukan penelitian yang bertujuan untuk melihat efektivitas logoterapi dalam meningkatkan konsep diri pada 60 pasien leukimia. Hasil menunjukkan bahwa logoterapi efektif dalam meningkatkan konsep diri, kepercayaan diri, serta kualitas hidup pasien leukimia. Ahmadi et al. (2017) juga melakukan penelitian yang bertujuan untuk melihat efektivitas logoterapi dalam 
meningkatkan konsep diri dan kesehatan secara umum pada 30 pasien Thalassemia yang berusia 18-25 tahun dan mendapatkan kesimpulan bahwa logoterapi merupakan intervensi yang efektif untuk meningkatkan konsep diri serta kesehatan pasien Thalassemia secara umum.

Di Indonesia, Rochmawati dan Febriana (2017) melakukan penelitian yang bertujuan untuk melihat efektivitas logoterapi untuk meningkatkan konsep diri dan kemampuan memaknai hidup pada 30 lansia yang berada di Panti Pelayanan Sosial. Hasil penelitian mengungkapkan bahwa logoterapi efektif untuk meningkatkan konsep diri dan kemampuan memaknai hidup pada lansia. Berdasarkan hasil studi literatur yang telah dijabarkan, penulis ingin mengetahui apakah logoterapi dapat meningkatkan konsep diri remaja di Indonesia, khususnya remaja yang berada di Lembaga Kesejahteraan Sosial maupun Panti Sosial

Pemberian logoterapi diharapkan membuat remaja yang berada di Panti $X$ dapat melihat diri dan dunianya dengan lebih positif, mampu mengambil sikap terhadap apa yang telah menimpanya, serta dapat menemukan potensi dalam dirinya yang dapat menjadi aset berharga untuk mempersiapkan masa depan yang lebih baik. Hal inilah yang membuat penulis tertarik untuk mengetahui keefektifan logoterapi untuk meningkatkan konsep diri remaja yang berada di Panti X Surabaya. Hipotesis dari penelitian ini adalah logoterapi efektif dalam meningkatkan konsep diri remaja yang berada di Panti X Surabaya.

\section{Metode}

Penelitian ini menggunakan penelitian kuantitatif dengan metode eksperimen true experimental, yakni pretest posttest control group design. Metode ini menggunakan dua kelompok, yakni kelompok eksperimen dan kelompok kontrol dengan adanya random assignment. Teknik pengambilan sampel dalam penelitian ini yakni non random sampling yaitu purposive sampling. Partisipan dalam penelitian ini merupakan remaja laki-laki yang berjumlah delapan orang dengan usia 13-18 tahun yang berada di Panti Sosial X. Partisipan memiliki skor Adolescents Self Concept Short Scale (ASCSS) yang berada dalam kategori rendah. Tabel 1 dan 2 menjelaskan mengenai gambaran profil partisipan yang telah dibagi menjadi dua kelompok secara random.

Tabel 1.

Gambaran Partisipan Penelitian Kelompok Eksperimen

\begin{tabular}{ccccccc}
\hline No & Partisipan & Pendidikan & Usia & Kategori & Skor ASCSS & Kategori \\
\hline 1. & BW & 1 SMK & 16 & Anak Nakal & 86 & Rendah \\
2. & CG & 6 SD & 15 & Anak Nakal & 88 & Rendah \\
3. & MD & 1 SMP & 13 & Anak Nakal & 86 & Rendah \\
4. & SS & 1 SMP & 15 & Anak Terlantar & 81 & Rendah \\
\hline
\end{tabular}


Tabel 2.

Gambaran Partisipan Penelitian Kelompok Kontrol

\begin{tabular}{ccccccc}
\hline No & Partisipan & Pendidikan & Usia & \multicolumn{1}{c}{ Kategori } & Skor ASCSS & Kategori \\
\hline 1. & AM & 6SD & 15 & Anak Terlantar & 89 & Rendah \\
2. & AA & 1 SMP & 15 & Anak Nakal & 86 & Rendah \\
3. & BG & 5 SD & 15 & Anak Terlantar & 81 & Rendah \\
4. & MR & 1 SMP & 14 & Anak Terlantar & 87 & Rendah \\
\hline
\end{tabular}

Alat pengumpul data dalam penelitian ini, yakni ASCSS (Adolescents Self Concept Short Scale). Skala ASCSS terdiri dari 30 aitem dan menggunakan skala likert dengan rentang 1-6, yakni (1) sangat tidak setuju, (2) tidak setuju, (3) sedikit tidak setuju, (4) sedikit setuju, (5) setuju, dan (6) sangat setuju. Terdapat enam dimensi dari alat ukur ASCSS, yakni: anxiety (kecemasan), physical appearance (penampilan fisik), behavior (perilaku), popularity (popularitas), happiness (kebahagiaan) dan intellectual (kemampuan intelektual) (Veiga \& Leite, 2016). Berdasarkan alat ukur ASCSS, konsep diri negatif diasosiasikan dengan konsep diri yang rendah sedangkan konsep diri positif diasosiasikan dengan konsep diri yang tinggi.

Pada validitas konstruk, setiap aitem memiliki faktor analisis dengan rentang 0,4500,881 . Sehubungan dengan hal itu, konsistensi internal total skor alat ukur ini adalah 0.87 dan masing-masing dimensi berkisar antara 0,70 - 0,79 (Veiga \& Leite, 2016). Analisis statistik yang dilakukan untuk mengetahui perbedaan gain score antara kelompok eksperimen dan kelompok kontrol menggunakan teknik parametrik, yakni independent sample t-test. Selain itu, untuk melihat seberapa besar efektivitas pemberian intervensi logoterapi dalam meningkatkan konsep diri remaja, juga akan dilakukan perhitungan dengan menggunakan effect size.

Intervensi logoterapi yang akan digunakan dalam penelitian ini diadaptasi dari Breitbart (2016) yakni Meaning Centered Psychotherapy (MCP). Intervensi ini terbagi menjadi delapan sesi. Tujuan intervensi $\mathrm{MCP}$ adalah untuk mengurangi keputusasaan serta mempertahankan dan/atau meningkatkan makna hidup. Gambaran umum dari masingmasing sesi dalam modul logoterapi dijelaskan pada tabel 3. 
Tabel 3.

Modul Logoterapi

\begin{tabular}{|c|c|c|}
\hline Sesi & Ta & Intervensi Logoterapi \\
\hline Pra-Sesi & - & $\begin{array}{l}\text { Perkenalan, membangun rapport, serta pengisian informed } \\
\text { consent }\end{array}$ \\
\hline $\mathbf{I}$ & $\begin{array}{l}\text { Apa makna hidup } \\
\text { itu? }\end{array}$ & $\begin{array}{l}\text { Melakukan diskusi mengenai definisi 'tujuan dan/atau } \\
\text { harapan hidup' serta mengeksplorasi pengalaman ketika } \\
\text { kehidupan terasa sangat berarti bagi partisipan. }\end{array}$ \\
\hline II & $\begin{array}{l}\text { Makna dalam } \\
\text { keterpurukanku }\end{array}$ & $\begin{array}{l}\text { Menceritakan mengenai 'WHO AM I?' dan siapa saja } \\
\text { yang berperan dalam membangun diri partisipan }\end{array}$ \\
\hline III & $\begin{array}{l}\text { Masa lalu yang } \\
\text { membuatku kuat }\end{array}$ & $\begin{array}{l}\text { Menceritakan mengenai kenangan di masa lalunya yang } \\
\text { paling signifikan bagi hidupnya }\end{array}$ \\
\hline IV & $\begin{array}{l}\text { Masa depan yang } \\
\text { membuatku } \\
\text { termotivasi }\end{array}$ & $\begin{array}{l}\text { Mengingat pencapaian di masa lalunya yang berdampak } \\
\text { besar bagi kehidupannya serta memahami bahwa masa } \\
\text { depan dapat membuat partisipan semakin bersemangat } \\
\text { untuk hidup }\end{array}$ \\
\hline V & $\begin{array}{l}\text { Menemukan } \\
\text { makna hidup dari } \\
\text { nilai bersikap }\end{array}$ & $\begin{array}{l}\text { Mengeksplorasi dan menceritakan kekhawatiran } \\
\text { mengenai ketidakjelasan masa depan dan permasalahan } \\
\text { mengenai keluarganya dan bagaimana harapan } \\
\text { partisipan mengenai hal tersebut }\end{array}$ \\
\hline VI & $\begin{array}{l}\text { Menemukan } \\
\text { makna hidup dari } \\
\text { nilai kreativitas }\end{array}$ & $\begin{array}{l}\text { Mengeksplorasi dan menceritakan pengalamannya ketika } \\
\text { mereka terhubung melalui pekerjaan dan/atau aktivitas } \\
\text { kreatif }\end{array}$ \\
\hline VII & $\begin{array}{l}\text { Menemukan } \\
\text { makna hidup dari } \\
\text { pengalaman }\end{array}$ & $\begin{array}{l}\text { Mengeksplorasi dan menceritakan pengalamannya ketika } \\
\text { mereka terhubung melalui cinta/kasih sayang, } \\
\text { keindahan/kebahagiaan, dan humor }\end{array}$ \\
\hline VIII & $\begin{array}{l}\text { I'm ready for the } \\
\text { new me! }\end{array}$ & $\begin{array}{l}\text { Pemberian posttest, melakukan evaluasi mengenai } \\
\text { keseluruhan kegiatan, dan menutup kegiatan intervensi }\end{array}$ \\
\hline
\end{tabular}

\section{Hasil}

Berikut merupakan hasil distribusi frekuensi partisipan penelitian pada saat sebelum intervensi (pretest) dan setelah intervensi (posttest) yang dibagi menjadi dua kelompok, yakni kelompok eksperimen dan kelompok kontrol. 


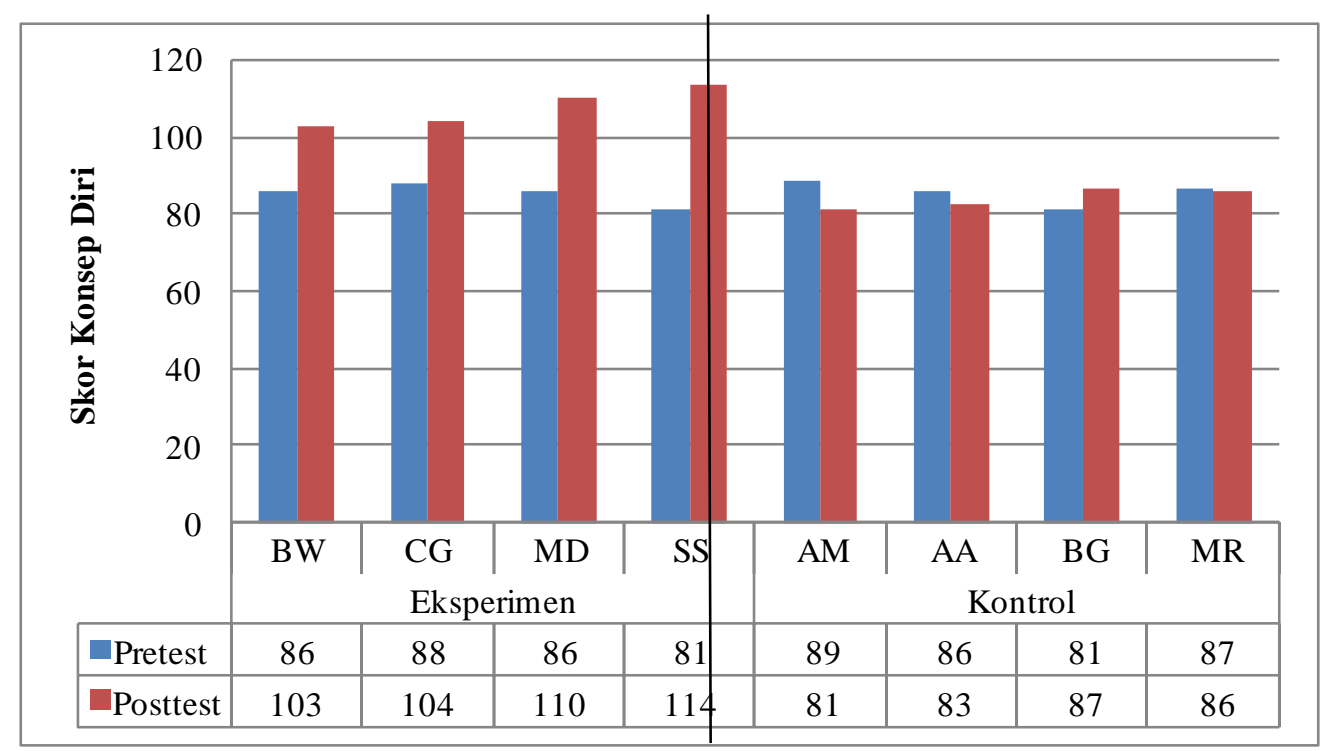

Grafik 1. Distribusi frekuensi Partisipan Penelitian

Berdasarkan grafik 1 dapat terlihat bahwa keseluruhan partisipan pada kelompok eksperimen menunjukkan peningkatan skor konsep diri setelah mengikuti intervensi logoterapi selama delapan sesi. Keseluruhan partisipan juga mengalami perubahan kategori dari yang semula memiliki konsep diri kategori rendah menjadi kategori sedang. Selain itu, keseluruhan kelompok kontrol memiliki kategori yang sama pada saat sebelum dan setelah diadakannya intervensi. Walaupun begitu, terdapat tiga orang yang mengalami penurunan skor dan satu orang lainnya mengalami peningkatan skor.

Tabel 4 dan 5 menjelaskan mengenai distribusi frekuensi serta hasil uji hipotesis independent sample t-test pada kelompok eksperimen dan kelompok kontrol berdasarkan selisih skor antara pretest dan posttest.

Tabel 4.

Distribusi Frekuensi Gain Score

\begin{tabular}{lllll}
\hline & Kelompok & N & Mean & SD \\
\hline \multirow{2}{*}{ Gain score } & Eksperimen & 4 & 22,50 & 7,85 \\
& Kontrol & 4 & $-1,50$ & 5,80 \\
\hline
\end{tabular}

Tabel 5.

Hasil Uji Hipotesis Independent Sample T-test

\begin{tabular}{cccccc}
\hline Variabel & $\boldsymbol{t}$ & Df & $\begin{array}{c}\text { Sig } \\
(\mathbf{2} \text { tailed })\end{array}$ & Mean diff. & Keterangan \\
\hline $\begin{array}{c}\text { Konsep } \\
\text { Diri }\end{array}$ & 4,9 & 6 & 0,003 & 24,00 & $\begin{array}{c}\text { Terdapat } \\
\text { perbedaan }\end{array}$ \\
\hline
\end{tabular}


Hasil menunjukkan bahwa $\mathrm{t}(6)=4,9, \mathrm{p}=0,003(\mathrm{p}<0,05)$ sehingga terdapat perbedaan yang signifikan pada konsep diri kelompok eksperimen maupun kelompok kontrol. Pada tabel 4 juga dijelaskan bahwa perbedaan rerata gain score pada kelompok eksperimen (mean= 22.50) lebih tinggi dibandingkan dengan kelompok kontrol (mean=-1,50). Hal ini dapat disimpulkan bahwa intervensi logoterapi dapat dikatakan efektif dalam meningkatkan konsep diri partisipan penelitian. Tabel 6 menjelaskan mengenai uji effect size yang dapat dilihat pada tabel berikut ini.

Tabel 6.

Hasil Uji Effect Size

\begin{tabular}{ccccc}
\hline Variabel & $\boldsymbol{t}$ & $\boldsymbol{N}$ & $\boldsymbol{R}$ & Kategori \\
\hline Konsep Diri & 4,9 & 4 & 0,80 & Besar \\
\hline
\end{tabular}

Hasil menunjukkan bahwa effect size bernilai 0,80 yang menjelaskan bahwa perbedaan jarak antara skor pretest dan postest pada kelompok eksperimen tergolong besar. Hal ini dapat disimpulkan bahwa intervensi logoterapi memberikan efek yang besar dalam meningkatkan konsep diri remaja di Panti Sosial.

\section{Diskusi}

Penelitian ini bertujuan untuk menjawab pertanyaan penelitian, yakni apakah logoterapi efektif untuk meningkatkan konsep diri remaja yang berada di Panti X Surabaya. Berdasarkan hasil analisis statistik, ditemukan perbedaan yang signifikan terkait konsep diri antara kelompok eksperimen dan kelompok kontrol jika dilihat dari gain score antara posttest dan pretest. Hasil penelitian ini sesuai dengan hipotesis yang telah diusulkan oleh peneliti dimana intervensi logoterapi efektif dalam meningkatkan konsep diri remaja yang berada di Panti X Surabaya.

Hasil penelitian ini juga didukung oleh beberapa penelitian yang telah dilakukan sebelumnya. Karimi dan Memarzadeh (2016) menjelaskan bahwa intervensi logoterapi membantu individu mampu untuk menerima kelemahan dan kelebihannya serta mampu untuk menerima pengalaman-pengalaman yang tidak menyenangkan di masa lalu dengan lebih berani sehingga konsep diri individu tersebut meningkat. Ahmadi et al. (2017) juga mengungkapkan bahwa logoterapi efektif dalam meningkatkan konsep diri dan kesehatan Pasien Thalassemia secara umum. Hal ini dikarenakan logoterapi dapat membantu dalam meningkatkan optimisme serta membantu individu dalam menemukan makna dalam diri mereka sehingga konsep diri mereka menjadi lebih positif dan mereka pun dapat bertindak secara bertanggung jawab terhadap tantangan kehidupan yang mereka hadapi.

Penelitian dari Rochmawati dan Febriana (2017) mengungkapkan bahwa intervensi logoterapi dapat meningkatkan konsep diri dan kemampuan memaknai hidup pada lansia. Hal ini dikarenakan logoterapi membantu individu untuk menyadari dan menerima keterbatasan yang ada, memberdayakan diri sendiri untuk melakukan aktivitas yang 
bermanfaat, serta mengeksplorasi mengenai harapan dan tujuan hidup. Logoterapi juga bertujuan agar individu terhindar dari perasaan hampa, putus asa, dan tidak berdaya sehingga secara langsung dapat meningkatkan konsep diri individu.

Konsep diri merupakan pengetahuan, pandangan, evaluasi, yang mempengaruhi seseorang dalam berperilaku sesuai dengan konsep mengenai dirinya tersebut (McCrae \& Costa dalam Feist \& Feist, 2008). Rochmawati (2014) mengungkapkan bahwa konsep diri positif dapat ditunjukkan dengan adanya penerimaan diri. Individu yang memiliki konsep diri positif akan lebih mampu untuk menerima kelemahan dan kelebihan dirinya, mampu untuk menerima pengalaman-pengalaman masa lalu yang menyakitkan, mampu merencanakan masa depan secara realistis, serta berani menghadapi segala tantangan pada kehidupan di masa depan. Hal ini juga terjadi pada setiap partisipan selama dan setelah diberikannya intervensi logoterapi.

Pada saat prasesi, subjek penelitian sangat aktif dan antusias dalam mengikuti intrevensi logoterapi. Subjek penelitian memiliki harapan yang positif dimana mereka ingin menjadi pribadi yang lebih baik lagi. Pada saat sesi pertama, beberapa subjek terlihat kesulitan untuk mengungkapkan tujuan hidupnya, pun mengingat pengalaman yang bermakna bagi subjek. Kesleuruhan subjek juga terlihat malu-malu dan tidak ingin untuk menjelaskan apa yang telah dituliskan. Namun setelah diminta untuk bercerita, subjek penelitian mampu untuk merefleksikan dan belajar dari pengalaman subjek lainnya bahwa mereka memiliki tujuan untuk tetap bertahan hidup setiap harinya. Mereka juga menyadari bahwa mereka memiliki pengalaman positif yang dapat digunakan sebagai kekuatan mereka ketika mereka merasa putus asa berada di Panti $X$ ini.

Pada sesi kedua, mayoritas subjek mengungkapkan bahwa mereka lebih mudah dalam menjelaskan kelemahan dibandingkan dengan kelebihannya. Namun ketika mereka diminta untuk merefleksikan, pun bertanya pada temannya terkait kelebihannya, mereka menjadi cukup percaya diri untuk menjelaskan hal tersebut. Mereka menyadari bahwa walaupun mereka memiliki kelemahan, mereka juga memiliki kelebihan. Mereka juga mengetahui bahwa yang membangun diri mereka menjadi saat ini adalah dari orang-orang terdekat mereka.

Pada sesi ketiga, mereka menyadari bahwa mereka memiliki pengalaman menyakitkan yang didapatkan oleh orang tua, keluarga terdekat, teman, bahkan pacar subjek. Ketika subjek penelitian bercerita, yang lain akan fokus mendengarkan, berempati, bahkan menyelingi humor untuk menertawakan kesakitan mereka. Walaupun menyakitkan, subjek mengetahui bahwa pengalaman itulah yang membuat subjek menjadi lebih kuat dan tangguh seperti sekarang. Mereka juga bersepakat bahwa jika diminta untuk mengulang waktu, subjek penelitian tidak ingin menghapus kenangan tersebut karena dari pengalaman menyakitkan itulah, subjek juga banyak mendapatkan pembelajaran berharga.

Pada sesi keempat, subjek mengungkapkan prestasi dan/atau pencapaian yang sudah subjek raih. Mayoritas subjek secara cepat mengungkapkan bahwa ia tidak memiliki prestasi apapun. Ketika peneliti berusaha memotivasi dan meminta subjek untuk mengingat pencapaian yang telah subjek dapatkan, subjek dapat mengungkapkan prestasi yang selama 
ini tidak ia pedulikan, pun menyadari bahwa subjek telah berjuang keras hingga saat ini. Subjek penelitian yang awalnya kesulitan untuk merancang masa depan mereka jadi memiliki harapan bahwa mereka bisa mendapatkan apa yang mereka mau ketika mereka berusaha semaksimal mungkin.

Pada sesi kelima, subjek menceritakan mengenai kekhawatirannya terkait masa depan pun kondisi mereka saat ini. Walaupun begitu, mereka mampu untuk menemukan makna hidup dengan bersikap. Mereka menyadari walaupun ada banyak hal di luar kendali mereka, namun mereka dapat memilih sikap untuk terus maju. Pada sesi keenam, subjek juga mampu menemukan makna hidup dengan nilai kreativitas. Subjek penelitian mulai mengeksplorasi hal-hal menyenangkan dan membahagiakan yang ia dapat lakukan. Pada sesi ketujuh, subjek penelitian mampu menemukan makna hidup dari nilai pengalaman, baik dari cinta kasih, humor, pun keindahan alam. Subjek penelitian mampu untuk mengeksplorasi hal-hal yang membuat subjek penelitian bahagia dengan terhubung bersama orang-orang terdekatnya. Pada sesi terakhir, keseluruhan subjek mengungkapkan bahwa mereka mendapatkan manfaat dan pembelajaran dari intervensi logoterapi yang diberikan.

Setelah diberikan intervensi logoterapi, partisipan menjadi mampu untuk menerima dan mulai memaafkan masa lalunya yang menyakitkan. Mereka mampu untuk menyadari bahwa walaupun mereka memiliki kekurangan, namun mereka juga diberkahi oleh kelebihan. Mereka juga menyadari bahwa terdapat banyak hal-hal yang tidak bisa mereka kontrol. Akan tetapi, mereka memiliki kemampuan untuk mengambil sikap dan komitmen atas hal tersebut. Mereka menyadari bahwa terdapat banyak sekali pencapaian-pencapaian yang telah mereka raih selama ini. Selain itu, mereka juga mampu untuk merencanakan masa depan dan mulai membuat daftar bagaimana cara mereka mencapai impiannya tersebut.

Berdasarkan keseluruhan rangkaian intervensi logoterapi, tahap terberat yang harus dilalui oleh partisipan adalah pada sesi tiga, yakni masa lalu yang membuatku kuat. Hal ini dikarenakan pada tahap ini, partisipan diminta untuk mengingat kembali pengalaman yang paling menyakitkan dan sangat berdampak bagi kehidupannya saat ini. Tahapan ini merupakan tahapan yang paling penting dalam intervensi logoterapi dikarenakan tahapan ini merupakan pintu bagi partisipan untuk mulai membuka diri pada penulis maupun partisipan yang lain. Maryatun et al. (2014) mengungkapkan bahwa logoterapi memberikan kebebasan individu untuk mengungkapkan permasalahannya sehingga mereka akan lebih mampu untuk menjelaskan perasaan berkaitan dengan permasalahan yang dialaminya.

Selain itu, tahapan penting lainnya dalam membentuk konsep diri subjek adalah pada sesi delapan, yakni menemukan makna hidup dari nilai pengalaman. Breitbart (2016) mengungkapkan bahwa terdapat empat cara dalam menemukan makna hidup, yakmi melalui nilai bersikap, nilai pengalaman, nilai kreativitas, maupun nilai warisan. Tahap ini merupakan tahapan yang paling disukai partisipan dikarenakan subjek mencoba untuk mengeksplorasi dan menghayati hal-hal positif di dalam kehidupannya ketika mereka terhubung melalui cinta/kasih sayang, keindahan/kebahagiaan, dan humor. Partisipan 
mengaitkan nilai pengalaman tersebut dengan orang-orang terkasih seperti keluarga, teman, maupun pacar.

Wong (dalam Maryatun, 2011) menjelaskan bahwa keberadaan diri seseorang akan bertahan lama dalam situasi dimana individu itu ada untuk orang lain. Hal ini dikarenakan individu dapat beradaptasi dan menikmati hidup yang dialaminya dengan bahagia bersama orang yang dicintainya. Wong (dalam Maryatun et al., 2014) juga menambahkan bahwa menghayati pun memaknai cinta kasih dapat memicu perasaan bahagia, puas, dan ketentraman diri sehingga membuat diri menjadi berharga dan lebih bermakna.

Salah satu faktor yang mendukung keberhasilan dari intervensi logoterapi adalah adanya keterbukaan dan keaktifan partisipan. Para partisipan aktif untuk mengerjakan setiap workbook maupun tugas yang diberikan, mendengarkan video dan materi yang penulis sampaikan, aktif dalam bertanya ketika ada yang tidak dimengerti, menanggapi pertanyaan dari penulis, serta saling berlomba untuk mempresentasikan hasil workbook nya terlebih dahulu. Maryatun et al. (2014) mengungkapkan bahwa sikap dan motivasi individu membuat intervensi berjalan secara maksimal dan akan mendukung tercapainya tujuan intervensi logoterapi. Selain itu, partisipan mau untuk terbuka untuk menjelaskan pengalaman-pengalaman menyakitkan yang pernah dialaminya, terbuka mengenai kelemahan dan kelebihan dirinya, serta mengenai rencana masa depannya. Martínez dan Flórez (2014) menjelaskan bahwa kesediaan individu untuk membuka diri terhadap ketidakpastian dan ketidaknyamanan yang dialami seringkali dihubungkan dengan perubahan positif dari intervensi logoterapi yang dijalaninya.

Hal lain yang memengaruhi keberhasilan intervensi adalah adanya diskusi dan berbagi pengalaman. Partisipan yang saling berbagi pengalaman akan membuat partisipan belajar dari pengalaman satu sama lain. Hal ini didukung oleh Whitaker (2001) yang menjelaskan bahwa terapi kelompok menyediakan lingkungan terapeutik sehingga menciptakan peluang bagi remaja untuk belajar bekerja sama dalam menangani permasalahan mereka sembari membandingkan diri mereka dengan rekan-rekan mereka. Berg et al. (2006) menambahkan bahwa mereka juga akan belajar cara yang tepat untuk mengungkapkan perasaan, menemukan bahwa mereka tidak sendirian, dan menemukan bahwa mereka dapat memberi serta menerima bantuan.

Walaupun demikian, terdapat beberapa keterbatasan yang ditemui oleh penulis saat memberikan intervensi logoterapi yakni: (a) hasil penelitian tidak mampu untuk digeneralisasikan di luar populasi sampel yang telah diambil. Hal ini dikarenakan penulis menggunakan metode pengambilan sampel yakni purposive sampling dimana penulis menetapkan suatu kriteria tertentu pada remaja Panti $X$ sebagai sampel penelitian. Selain itu, jumlah sampel penelitian juga relatif sedikit dikarenakan adanya keterbatasan jumlah remaja yang sesuai dengan karakteristik penelitian sehingga hanya terdapat empat remaja pada masing-masing kelompok, (b) kuesioner dari alat ukur yang digunakan untuk mengukur konsep diri merupakan alat ukur yang belum pernah diujikan secara luas dengan jumlah subjek yang banyak; serta (c) banyaknya kegiatan anak asuh yang berada di Panti X seringkali menjadi hambatan dikarenakan anak asuh sudah terlalu lelah untuk mengikuti 
kegiatan intervensi logoterapi. Hal ini membuat penjadwalan pada pertemuan setiap minggunya menjadi kurang terstandar.

\section{Kesimpulan}

Intervensi logoterapi terbukti efektif untuk meningkatkan konsep diri pada remaja yang berada di Panti X Surabaya. Partisipan merasakan adanya perubahan positif setelah mendapatkan intervensi diantaranya mereka dapat memaafkan masa lalu yang menyakitkan, lebih positif dalam memandang dirinya sendiri dan memiliki rencana masa depan yang lebih baik dan spesifik dibanding sebelumnya. Tahap terberat yang harus dilalui oleh subjek penelitian adalah pada sesi tiga, yakni berkaitan dengan masa lalu. Tahapan ini merupakan tahapan yang paling penting dalam intervensi logoterapi dikarenakan tahapan ini merupakan pintu bagi subjek penelitian untuk mulai membuka diri. Selain itu, tahapan penting lainnya dalam membentuk konsep diri subjek adalah pada sesi menemukan makna hidup. Sesi yang paling disukai subjek yakni sesi ke tujuh dikarenakan subjek mencoba untuk mengeksplorasi dan menghayati hal-hal positif di dalam kehidupannya ketika mereka terhubung melalui cinta/kasih sayang, keindahan/kebahagiaan, dan humor.

\section{Saran}

Peneliti selanjutnya dapat mengkaji kembali dan mengembangkan metode logoterapi yang berbeda maupun intervensi yang berbeda agar dapat menjaga atau bahkan meningkatkan konsep diri remaja. Selain itu, peneliti selanjutnya dapat mengembangkan intervensi logoterapi namun dalam setting yang berbeda, misalnya: panti asuhan ataupun yayasan pondok sosial lainnya. Hal ini dilakukan untuk membuktikan bahwa intervensi logoterapi juga dapat diterapkan pada berbagai setting penelitian.

\section{Kepustakaan}

Ahmadi, F. S., Samavi, S. A., \& Najarpurian, S. (2017). Evaluating the effectiveness of logo therapy on the increase of positive self-concept and general health of the thalassemia patients. American Journal of Life Science Researches, 5(4), 184-192. http://dx.doi.org/10.21859/ajlsr-05047

Andriasari, F. (2015). Konsep diri pada anak sekolah dasar dan menengah pertama. Seminar Psikologi \& Kemanusiaan, 487-491.

Berg, R. C., Landreth, G. L., \& Fall, K. A. (2006). Group counseling: Concepts and procedures (Edisi keempat). Taylor \& Francis Group, LLC.

Breitbart, W. (2016). Meaning-centered psychotherapy (MCP) for advanced cancer patients. Dalam A. Batthyany (Ed.). Logotherapy and existential analysis: Proceeding of the Viktor Frankl Institute Vienna. Springer International Publishing Switzerland. 
Corey, G. (2013). Teori dan praktek konseling dan psikoterapi. PT Refika Aditama.

Desmita. (2005). Psikologi perkembangan. PT Remaja Rosdakarya.

Dinas Sosial Kota Surabaya. (2016). Buku panduan pendampingan campus social responsibility (CSR). Dinas Sosial Kota Surabaya.

Doğan, T., Sapmaz, F., Tel, F.D., Sapmaz, S., \& Temizel, S. (2012). Meaning in life and subjective well-being among turkish university students. Social Behavioral Sciences, 55, 612-617. http://dx.doi.org/10.1016/j.sbspro.2012.09.543

Erlangga, E. (2017). Terapi kelompok dengan teknik logoterapi untuk meningkatkan penerimaan anak broken home. Jurnal Penelitian Pendidikan Indonesia, 2(1), 1-6.

Feist, J., \& Feist, G. J. (2008). Theories of personality (Edisi ketujuh). McGraw-Hill.

Kampung Anak Negeri. (2018). Profil UPTD Kampung Anak Negeri. Company Profil Kampung Anak Negeri.

Kang, K. A., Im, J. I., Kim, H. S., Kim, S. J., Song, M. K., \& Sim, S. Y. (2009). The effect of logotherapy on the suffering, finding meaning, and spiritual well-being of adolescents with terminal cancer. Journal Korean Academy Health Nursing, 15(2), 136-144. http://dx.doi.org/10.4094/jkachn.2009.15.2.136

Karimi, S., \& Memarzadeh, M. (2016). The effect's of logotherapy on self-concept scale in iranian leukemia patients: Seyed Alshohada Hospital in Isfahan Province. International Journal of Humanities and Cultural Studies, 2113-2119.

Marliani, R. (2016). Psikologi perkembangan anak dan remaja. CV Pustaka Setia.

Martínez, E. Y., \& Flórez, I. A. (2014). Meaning-centered psychotherapy: A Socratic clinical $\begin{array}{llll}\text { practice. Journal of Contemporary Psychotherapy, 45(1), 37-48. } & \text {. }\end{array}$ http://dx.doi.org/10.1007/s10879-014-9281-0

Maryatun, S. (2011). Pengaruh logoterapi terhadap perubahan harga diri narapidana perempuan dengan narkotika di lembaga pemasyarakatan kelas IIA Palembang (Manuskrip tidak terpublikasi). Fakultas Ilmu Keperawatan, Universitas Indonesia.

Maryatun, S., Hamid, A. Y. S., Mustikasari. (2014). Logoterapi Meningkatkan Harga Diri Narapidana Perempuan Pengguna Narkotika. Jurnal Ilmu Keperawatan Indonesia, 17(2), 48-56. http://dx.doi.org/10.7454/jki.v17i2.441

Mazaya, K. N., \& Supradewi, R. (2011). Konsep diri dan kebermaknaan hidup pada remaja di panti asuhan. Proyeksi, 6(2), 103-112. http://dx.doi.org/10.30659/p.6.2.103-112

Nasti, S. H. (2016). Konsep diri anak jalanan (Manuskrip tidak terpublikasi). Fakultas Psikologi, Universitas Muhammadiyah Surakarta

Obioha, E. E. (2009). Becoming a street child in poverty ridden society: A descriptive case of Kaduna Metropolis, Nigeria. Journal of Social Sciences, 19(1), 41-49. http://dx.doi.org/10.1080/09718923.2009.11892689

Overton, W. F. (2010). Life-span development. Dalam R.M. Lerner, M.E. Lamb and A.M. Freund, The Handbook of Life-Span Development. https://doi.org/10.1002/9780470880166.hlsd001001

Papalia, D. E., Olds, S. W., \& Feldman, R. D. (2004) Human development (Edisi kesembilan). McGraw-Hill. 
Pardede, Y. O. (2008). Konsep diri anak jalanan usia remaja. Jurnal Psikologi, 1(2), 146-151.

Putri, D. R. (2017). Pelatihan berpikir positif terhadap konsep diri remaja yang tinggal di panti asuhan. Psikologika: Jurnal Pemikiran dan Penelitian Psikologi, 22(1), 69-81. http://dx.doi.org/10.20885/psikologika.vol22.iss1.art5

Rathus, S. A. (2017). Childhood and adolescence: Voyages in development (Edisi kelima). Cengage Learning.

Robatmili, S., Sohrabi, F., Shahrak, M.A., Telepasand, S., Nokani, M., \& Hasani, M. (2014). The effect of group logotherapy on meaning in life and depression levels of Iranian students. International Journal for the Advancement of Counselling, 37(1), 54-62. http://dx.doi.org/10.1007/s10447-014-9225-0

Rochmawati, D. H. (2014). Hubungan antara konsep diri dan kemampuan memaknai hidup pada narapidana remaja di Lembaga Pemasyarakatan Kelas 1 Semarang. Jurnal Keperawatan Soedirman, 9(3), 198-204. http://dx.doi.org/10.20884/1.jks.2014.9.3.614

Rochmawati, D. H., \& Febriana, B. (2017). Efektifitas logoterapi dalam meningkatkan konsep diri dan kemampuan memaknai hidup pada lansia. Jurnal Perawat Indonesia, 1(1), 2631. http://dx.doi.org/10.32584/jpi.v1i1.6

Sebastian, C., Burnett, S., \& Blakemore, S. (2008). Development of the self-concept during adolescence. Trends in Cognitive Science, 12(11), 441-446. http://dx.doi.org/10.1016/j.tics.2008.07.008

Shoaakazemi, M., Javid, M. M., Tazekand, F. E., Khalili, S. (2012). The effect of logo therapy on improving the quality of life in girl students with PTSD. Life Science Journal, 9(4), 5692-5698.

Veiga, F., \& Leite, A. (2016). Adolescents' Self-Concept Short Scale: A version of PHCSCS.

Social and Behavioral Sciences, 217, 613-617.

http://dx.doi.org/10.1016/j.sbspro.2016.02.079

Whitaker, D. S. (2001). Using groups to help people (Edisi kedua). Brunner-Routledge. 